\title{
Sustainability in Alternative Food Networks: A Systematic Literature Review
}

\author{
Rosario Michel-Villarreal ${ }^{1, *} \mathbb{C}$, Martin Hingley ${ }^{1}\left(\mathbb{D}\right.$, Maurizio Canavari $^{2}\left(\mathbb{D}\right.$ and Ilenia Bregoli ${ }^{1}$ \\ 1 Lincoln International Business School, University of Lincoln, Brayford Wharf East, Lincoln LN5 7AT, UK; \\ mhingley@lincoln.ac.uk (M.H.); ibregoli@lincoln.ac.uk (I.B.) \\ 2 Dipartimento di Scienze e Tecnologie Agro-Alimentari, Alma Mater Studiorum-Università di Bologna, \\ viale Giuseppe Fanin 50, 40127 Bologna, Italy; maurizio.canavari@unibo.it \\ * Correspondence: rmichelv@lincoln.ac.uk; Tel.: +44-1522-835509
}

Received: 30 December 2018; Accepted: 2 February 2019; Published: 7 February 2019

\begin{abstract}
In recent years, increasing attention has been paid to individuals' organizing themselves and managing food systems in an 'alternative' and more sustainable way. Such emerging food initiatives are most commonly known as 'Alternative Food Networks' (AFNs). However, there is an ongoing debate concerning the extent to which AFNs facilitate social, economic and environmental change. There are criticisms of the overall sustainability promise of AFNs related to sufficiency of impact, possible counter effects and the relevance of impacts. Because empirical studies often only focus on specific sustainability issues or AFNs, it has been difficult to develop more robust theories about the relations between diverse AFNs arrangements and sustainability. Thus, the aim of this paper is to contribute towards reducing this knowledge gap through a systematic literature review on AFNs in relation to sustainability. We summarize main methodological approaches, the types of AFNs studied and sustainability dimensions addressed in literature to date. Findings serve as reference to propose opportunities for future research regarding sustainability in AFNs.
\end{abstract}

Keywords: alternative food networks; systematic literature review; sustainability

\section{Introduction}

In 1987 the "sustainability revolution" started to speed up following the publication of "The Brundtland report' by the World Commission on Environment and Development. The most accepted definition of sustainable development was conceived then as " ... development that meets the needs of the present without compromising the ability of future generations to meet their own needs" [1]. Since then, the idea of sustainable development has been widely used and given an important position in the international political agenda. Nevertheless, achievement of a sustainable future seems more distant with every passing day. The increasingly evident inability of the climate to assimilate the amount of greenhouse gases currently in the atmosphere is sounding alarms about the impact of human activity. As McKibben [2] (p. 18) points out, "even before we run out of oil, we're running out of planet". Over the past two centuries, we have mined it, burned it, eroded it, cut it down, and polluted it in the name of development. The planet is deteriorating, and we have surpassed many planetary limits that "define the safe operating space for humanity with respect to the Earth system" [3] (p. 472).

Our food system is directly dependent on the health of the Earth system. At the same time, agriculture is one of the major contributors to human impact on Earth's ecosystems with up to thirty percent of global greenhouse gas emissions attributed to it [4]. Currently, "our soils, freshwater, oceans, forests and biodiversity are being rapidly degraded" [5], and the food system is failing us. In 2017, The State of Food Security and Nutrition in the World 2017 report acknowledged that after decades of consistent decline, global hunger increased for the first time in 2016 and now affects 
$11 \%$ of the world's population [6]. Although the productive potential of agriculture has surpassed population growth [4], the recent decrease in food security is closely linked to conflict, economic slowdowns and weather-related events; partly and probably due to climate change [6]. Moreover, agricultural intensification that led to increases in food availability is already having major effects on the environment; and has proved insufficient to improve the socio-economic conditions of farmers. As of 2015,75 percent of the world's poor lived in rural areas. Working in agriculture is closely related to poverty and extreme poverty status in each region of the world [7].

According to Hardin [8], the ways in which people organize themselves to exploit natural resources (i.e., institutional arrangements) is one of the human factors driving environmental change. Expanding on this, Dietz et al. [9] suggest that in the absence of effective governance or institutional arrangements, natural resources and the environment are threatened by patterns of consumption, population growth and technological advances. This view resonates with current criticisms of the 'conventional' food system. Most recently, the United Nations [5] (p. 1) recognized that "a profound change of the global food and agriculture system is needed to nourish today's 795 million hungry and the additional 2 billion increase in global population expected by 2050". In particular, changes are needed to improve productivity and sustainability of food systems, and the livelihoods of small-scale food producers.

It is beyond the scope of this paper to discuss in detail 'conventional' food systems, their characteristics or the difficulties in drawing a distinction between the 'conventional' and other forms of food provisioning [10]. However, for the sake of clarity, we view 'the conventional' food system as that which relies on conventional agriculture as conceptualized by Beus and Dunlap [11]. Thus, the 'conventional' food system is one based on large-scale, highly mechanized and industrialized agriculture with an increased use of monocultures, fertilizers and pesticides. Furthermore, because of globalization, 'conventional' food systems are also characterized by long food supply chains (with many food miles and nodes) which often include supermarkets as outlets for final consumers [12].

Overall, evidence seems to suggest that the current institutional arrangements of the 'conventional' food system are inadequate to ensure sustainability. In this context, increasing attention has been focused on the study of alternative approaches for managing our food system. Many case studies about individuals organizing themselves and managing food systems in an alternative way have been documented over the past two decades. The phenomena have been linked to broader concepts such as locality, quality, spatiality, embeddedness and sustainability. Farmers' markets, community-supported agriculture, box schemes, cooperatives, farm shops and other initiatives have been used to exemplify these alternative approaches [13]. Goodman et al. [14] suggest that the importance of these initiatives lies in the fact that we will not be able to meet our sustainability challenges without them.

The phenomena have been studied from various theoretical perspectives and with the use of different conceptual headings such as alternative food networks (AFNs) $[10,15,16]$, short food supply chains $[13,17]$ and more recently civic food networks $[18,19]$. In this paper we adopt the theoretical perspective that uses the concept of alternative food networks. For our literature review, this provided a necessary theoretical and conceptual focus but also allowed us to collect a large number of studies as the concept of AFNs has been widely used to explore these phenomena since the 1990s.

\subsection{Alternative Food Networks}

One of the earliest definitions of AFNs suggests that they are "rooted in particular places, [and] aim to be economically viable for farmers and consumers, use ecologically sound production and distribution practices, and enhance social equity and democracy for all members of the community" [20] (p. 2). Jarosz [21] suggests that AFNs are characterized by shorter distances between producers and consumers, farming methods that contrast with those of large-scale agri-businesses, commitment to sustainability and the existence of certain food purchasing venues (i.e., cooperatives, farmers' markets, community supported agriculture-CSA, etc.). The literature tends to describe AFNs as somehow oppositional to 'conventional' food systems [22-24]. This view is justified based on the 
ability of AFNs to reconnect producers and consumers $[25,26]$ and the capacity to create proximate or embedded forms of food provisioning $[27,28]$. As a consequence, AFNs are said to have the potential to enhance re-distribution of value for producers and to facilitate the production of sustainably grown goods. Even though a wealth of definitions have been proposed, Tregear [29] recognizes a lack of clarity with regards to the overall concept of AFNs, suggesting that the concept is universally used to describe systems that differ from the 'conventional' or is usually defined by what it is not, instead of what it is.

Some frameworks to categorize AFNs have also been proposed. For instance, Renting et al. [17] (p. 399) suggested a framework to explain the empirical variety of producer-consumer relations within AFNs, or Short Food Supply Chains (SFSCs) as they call them, based on their "organizational structure and the specific mechanisms entailed in these to extend relations in time and space. They divide AFNs into three groups: Face-to-face SFSCs (involving direct interaction between producers and consumers), Proximate SFSCs (based on relations of proximity) and Extended SFSCs (where interaction of producers and consumers is not direct, and connections are established through qualities embedded in the products). Watts et al. [16] categorize AFNs as "weaker" or "stronger" depending on the extent to which they challenge principles of conventional food networks. On the one hand, "weaker" AFNs are those whose alternativeness rely on qualities of the products, such as fair trade, organic and denomination or origin. By contrast, "stronger" AFNs are those that involve networks that do not conform to those of the conventional food system, such as farmers' markets (direct selling), community-supported agriculture and box schemes.

Maye and Kirwan [23] suggest that 'alternativeness' depends on the context, which implies the need to examine the unique ordering and spatiality of individual initiatives. The geographical distribution of AFN studies and the variety of AFN arrangements have not been reviewed previously.

Regarding sustainability, there is an ongoing debate concerning the extent to which AFNs are able to facilitate social and environmental change [30]. According to Tregear [29], a problematic feature of the study of AFNs relates to the preconceived assumption that because of their nature, unconventional food networks inherently offer economically, socially and environmentally desirable outcomes. This is, to some extent, similar to the 'local' trap, which is the tendency to assume that local-scale food systems are inherently good [31]. Thus, often AFNs are uncritically deemed to be 'good' or 'sustainable' without a comprehensive analysis of how or to what extent they challenge practices related to conventional food systems [32,33]. This lack of clarity may limit the opportunities for constructive change that AFNs may facilitate [34].

There are also criticisms of the overall sustainability promise of AFNs related to sufficiency of impact, possible counter effects and relevance of impacts. Because studies often only focus on specific sustainability issues [35], it has been difficult to develop more robust theories about the relationship between diverse AFNs institutional arrangements and sustainability. For instance, Hedberg [36] explains that even though the environmental sustainability of AFNs has been explored to some extent, most studies rely on the use of metrics related to 'food miles', a concept that is easy to communicate to consumers [37-39]. Only a few studies have explored the relationship between AFNs and the conditions at the producer's end of the network [40]. In regard to the socio-economic dimensions of sustainability, concerns have also been raised. For instance, James [41] suggests that empirical evidence concerning the impact of AFNs on the economic viability of farmers is scarce. Thus, it is still unclear to what extent AFNs can positively impact the socio-economic and environmental contexts where farmers operate.

Overall, the study of AFNs in relationship to sustainability presents several opportunities for further research at present. Based on the empirical evidence that has accumulated in the last decade, we carry out a systematic literature review of AFNs to investigate how sustainability has been studied in the context of these phenomena. This study is guided by the following research questions:

RQ1. What methodological approaches have been used in the study of sustainability within AFNs? 
RQ2. What types of AFNs have been studied in relation to sustainability?

RQ3. What dimensions of sustainability have been studied within AFN literature?

For the analysis of sustainability dimensions (RQ3) we adopt the most common framework for the conceptualization of sustainability. It consists of three main dimensions: environmental, social and economic, usually represented by three interlocking circles or pillars [42-45]. According to the United Nations [46], sustainability can only be achieved through the balance and integration of its three dimensions.

The remainder of this article is structured as follows. In the next section, we provide an overview of the process followed to conduct the systematic literature review. Then, we summarize the data extracted from the reviewed literature using descriptive statistics and cross tabulations. Lastly, we discuss the main results from the analysis and propose ways to advance research in relation to sustainability within AFNs.

\section{Materials and Methods}

We chose the systematic literature review (SLR) methodology to address the research questions posed in the previous section. This methodology has been recognized as a powerful tool for evaluating, summarizing and disseminating evidence about a given research topic. It is said to minimize bias by adopting a more transparent process of review that increases replicability [47,48]. Consistent with other recent systematic literature reviews (SLRs) published in the field of sustainability [49-51] we adopted the three-stage approach to SLRs proposed by Tranfield et al. [48] as depicted in Figure 1. The SLR was conducted from January 2018 to May 2018.

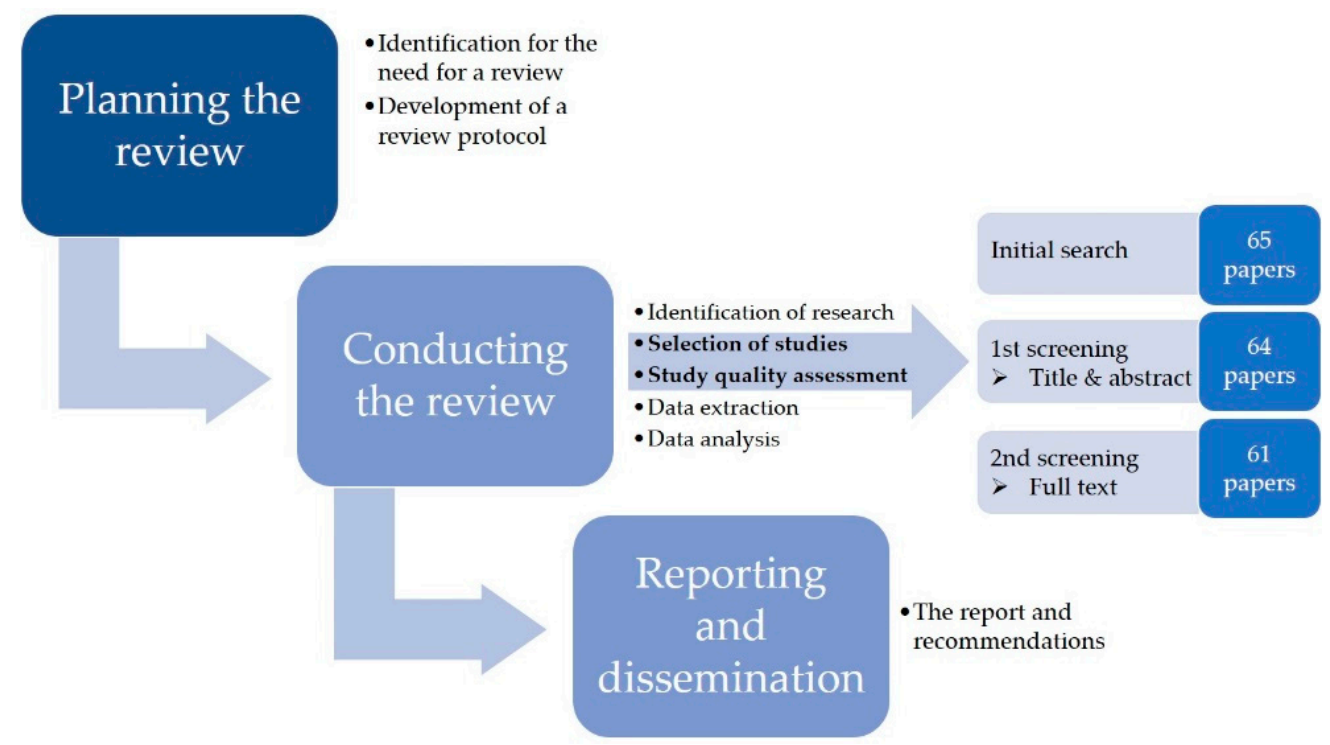

Figure 1. Systematic literature review process (adapted from [48]).

\subsection{Stage 1: Planning the Review}

Prior to starting this SLR, we identified the need for a review based on a conceptual discussion that led to the identification of the research questions stated in Section 1.1. In order to address these questions, we needed to review all the literature concerning AFNs and sustainability. To keep the search as broad as possible, we only established key words related to these two concepts. We chose the scientific Scopus-Elsevier database to carry out our search. Scopus-Elsevier is one of the most comprehensive databases and has been recognized as containing more high-quality, peer-reviewed publications than other databases [49]. Following this, the inclusion and exclusion criteria were established: we ensured the selection of relevant papers by limiting the search to papers containing 
the defined key words in the title, abstract or key words section. We also limited the search to English-language documents only. The type of document was limited to "article". No restrictions were established in terms of year of publication. The search in Scopus was conducted in January 2018. Thus, papers published in 2018 are not included in the review. The final search string used is the following:

TITLE-ABS-KEY ("alternative food network" OR "AFNs" OR "AFN" AND sustaina*) AND (LIMIT-TO (DOCTYPE,"ar")) AND (LIMIT-TO (LANGUAGE,"English")).

\subsection{Stage 2: Conducting the Review}

After the initial search in Scopus, our first sample consisted of 65 papers. We conducted a first screening of titles and abstracts to assess the relevance or pertinence and quality of the papers. One publication was dropped because it was not a peer-reviewed article. During a second screening of full papers we dropped another three papers because the main focus of the research was not sustainability. Thus, the final sample consisted of 61 papers (see Appendix A). At this point, we created a database using Excel in order to collect data from the selected papers. We considered it pertinent to extract the following information to answer our research questions: (1) Title, (2) Authors, (3) Year of publication, (4) Country, (5) Methodological approach, (6) Research methods, (7) Types of AFNs studied, (8) Participants involved in the research, (9) sustainability dimensions addressed (i.e., social, economic and environmental) and (10) Topics.

First, we conducted descriptive analysis to identify trends in all extracted data. Following this, cross tabulations were conducted to identify relationships between different data. For instance, the relationship between the sustainability dimensions addressed and the participants involved in studies was examined.

\subsection{Stage 3: Reporting and Dissemination}

In line with the recommendation of Tranfield et al. [48], the summary and dissemination of our findings was divided into two sections. The first section provides a full descriptive analysis of extracted data. First, we characterized the sample by summarizing key variables such as year of publication and countries targeted in papers. Next, a full review of other extracted data is provided, by means of tables and charts. The second section of our summary includes an overview of key emerging themes in relation to the three dimensions of sustainability. This section also addresses the research questions guiding this study.

\section{Results}

Figure 2 presents an overview of the evolution of publications by year. In our sample, the first two papers about AFNs that explicitly consider sustainability were published in 2006. Since then, there has been a slow but steady increase in the number of publications addressing sustainability. In 2016, right after the publication of the UN Sustainable development goals, the number of publications increased substantially, and the trend has been maintained since then.

Next, we analyzed the targeted countries in our sample. Out of 61 papers in our sample, 53 papers mentioned which country or countries their study was focused on. In these 53 papers, there are 56 indications of countries, as some papers focused their research on more than one country. For instance, one study carried out research in the UK and Canada, another one in the UK and Finland and a last one in Poland and Czech Republic (now Czechia). Results suggest that most frequently studies have targeted the USA (20\%), Czechia and the UK (13\% respectively) and Italy (11\%). Table 1 shows the complete list of the countries that were targeted. 


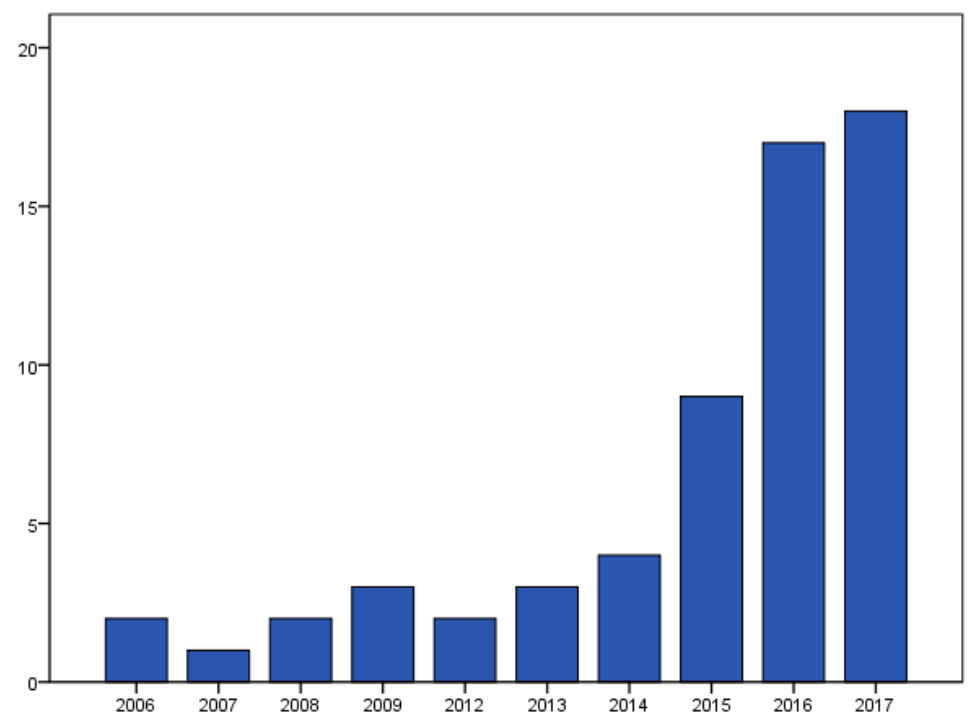

Figure 2. Number of papers published by year. Note: Our elaboration.

Table 1. Countries targeted in empirical studies. Note: Our elaboration.

\begin{tabular}{cccccc}
\hline $\begin{array}{c}\text { Targeted } \\
\text { Countries }\end{array}$ & Frequency & $\begin{array}{c}\text { Targeted } \\
\text { Countries }\end{array}$ & Frequency & $\begin{array}{c}\text { Targeted } \\
\text { Countries }\end{array}$ & Frequency \\
\hline USA & 11 & Finland & 2 & Germany & 1 \\
Czechia & 7 & Bolivia & 1 & India & 1 \\
UK & 7 & Brazil & 1 & Mexico & 1 \\
Italy & 6 & Bulgaria & 1 & Poland & 1 \\
Australia & 4 & Denmark & 1 & Romania & 1 \\
Canada & 4 & Ecuador & 1 & Vietnam & 1 \\
Spain & 3 & France & 1 & & \\
\hline
\end{tabular}

Taking as reference the socio-economic and political North-South divide, results show that there are only six indications of countries located in the Global South. That is, only $11 \%$ of studies in our sample focused specifically on countries located in the Global South.

\subsection{Methodological Approaches}

To better understand the methodological approaches that have been used in the study of AFNs and sustainability, we identified the research design adopted in the papers of our sample. We first classified papers as (1) empirical, (2) theoretical and (3) literature reviews. Out of 61 papers, 51 (83\%) are empirical studies, $9(15 \%)$ are theoretical studies and $1(2 \%)$ is a literature review. These results show a marked preference for empirical studies when researching sustainability issues within AFNs.

Second, we analyzed whether empirical papers adopted mono-method or multi-method approaches. Out of 51 empirical papers, 21 (41\%) used mono-method approaches and the rest (59\%) adopted multi-method approaches. Out of the 30 papers that adopted a multi-method approach, 15 used two methods, 11 used three methods and only 4 used four methods. Thus, there is a slight preference for using multi-method approaches with two methods being the most preferred multi-method approach.

Regarding the research methods used in the empirical papers of our sample, interview was the preferred method used in 39 out of 51 papers. This was followed by survey, which was used in 18 papers $(35.3 \%)$, participant observation was used in 14 papers $(27.5 \%)$ and case study and documentary analysis used in 9 papers $(17.6 \%)$ respectively. Table 2 displays other methods that were used to a lesser extent within the empirical studies of our sample. 
Table 2. Research methods used in empirical papers. Note: Our elaboration.

\begin{tabular}{cc}
\hline Research Methods & Frequency \\
\hline Interviews & 39 \\
Survey & 18 \\
Participant observation & 14 \\
Case study & 9 \\
Documentary analysis & 9 \\
Secondary data & 7 \\
Focus group & 4 \\
Field visits & 3 \\
Non-participant observation & 3 \\
Case vignettes & 1 \\
Consumer diaries & 1 \\
\hline
\end{tabular}

As part of the analysis of empirical papers, we also examined the different types of AFNs that have been targeted and studied. We identified nineteen different organizational arrangements that authors classified as AFNs and targeted in their studies (see Table 3). The most common AFN studied in empirical papers is Community Supported Agriculture, which was used in 8 of 51 papers $(15.7 \%)$. This is followed by Farmers markets used in 7 papers (13.7\%) and Organic farms used in 6 papers $(11.8 \%)$. Other types of AFNs were used in less than $10 \%$ of the papers in our sample. For instance, Cooperatives and Solidarity Purchasing Groups were used in 5 papers $(9.8 \%)$ respectively and Farm Shops and Urban Agriculture were used in 4 papers (7.8\%) each. Other less common AFNs were used in just one paper of our sample (i.e., E-commerce, Fairtrade, Food self-provision, Pastured poultry and Slow food event).

Table 3. Types of AFNs studied in empirical papers. Note: Our elaboration.

\begin{tabular}{cc}
\hline Types of AFNs studied & Frequency \\
\hline Community Supported Agriculture & 8 \\
Farmers markets & 7 \\
Organic farms & 6 \\
Cooperatives & 5 \\
Solidarity Purchasing Groups (GAS) & 5 \\
Farm shops & 4 \\
Urban Agriculture & 4 \\
Box scheme & 3 \\
Community gardens & 3 \\
Organized Groups of Supply and Demand & 2 \\
Allotment & 2 \\
Direct sales & 2 \\
E-commerce & 1 \\
Fairtrade & 1 \\
Food self-provision & 1 \\
Pastured poultry & 1 \\
Slow food event & 1 \\
Vending machines & 1 \\
Wild food networks & 1 \\
\hline
\end{tabular}

To better understand the diversity of AFNs studied in empirical papers up to date, we also analyzed how many different types of AFNs (from those listed in Table 3) have been used in each empirical paper. Out of 51 empirical papers, 35 targeted specific types of AFNs. These papers carried out research within specific AFNs or carried out research that relates to specific AFNs arrangements. Results show that 25 papers (71\%) only look at one type of AFN, 5 papers (14\%) investigated two different types of AFNs, 3 papers studied four different types of AFNs, only one paper looked at five 
different types of AFNs and another one looked at six different types of AFNs. Results in Table 4 show that the majority of empirical studies related to sustainability in AFNs only look at one type of AFN.

Table 4. Number of different types of AFNs studied in empirical papers. Note: Our elaboration.

\begin{tabular}{cc}
\hline Types of AFNs Studied & Frequency \\
\hline One & 25 \\
Two & 5 \\
Four & 3 \\
Five & 1 \\
Six & 1 \\
\hline
\end{tabular}

Next, we analyzed the participants that were targeted in the empirical studies of our sample. Out of 51 empirical studies, only 44 explicitly targeted and defined specific participants. Results suggest that authors involved a wide variety of participants in their studies. The most common participants were 'producers', who were involved in 35 empirical studies (79\%). This is followed by 'consumers', who participated in 20 studies (45.4\%). The frequency of participation of other participants is much lower. For instance, 'managers' of AFNs only participated in 5 studies (11\%) and 'activists' and 'organizers' of AFNs only participated in 4 studies (9\%) respectively. Table 5 shows a complete list of different types of participants that were involved in empirical studies of our sample.

Table 5. Participants targeted in empirical studies. Note: Our elaboration.

\begin{tabular}{cc}
\hline Participants & Frequency \\
\hline Producers & 35 \\
Consumers & 20 \\
Managers & 5 \\
Activists & 4 \\
Organisers & 4 \\
Government officials & 3 \\
Non-Governmental Organisations & 3 \\
Researchers & 3 \\
Retailers & 3 \\
Farm workers & 2 \\
Community leaders & 1 \\
Creators of online spaces & 1 \\
Decision makers within the food manufacturing sector & 1 \\
Distributors & 1 \\
Farm suppliers & 1 \\
Landowners & 1 \\
Plant workers & 1 \\
Representatives of AFNs & 1 \\
Sustainability directors & 1 \\
Urban designers & 1 \\
Volunteers & 1 \\
Wholesalers & 1 \\
\hline
\end{tabular}

Lastly, we analyzed the number of different participants involved in empirical studies. Results show that 18 papers involved only one type of participant, 12 papers engaged with two different types of participants, 8 papers used three different types of participants, 4 papers engaged with four different types of participants and only 2 papers involved five different types of participants.

\subsection{Sustainability Dimensions}

Regarding the dimensions of sustainability addressed in the papers of our sample, results show that 32 out of 61 papers (52\%) consider the social, economic and environmental dimensions 
of sustainability to some extent. Furthermore, 10 papers $(16 \%)$ address the social and economic dimensions of sustainability and 6 papers $(9.83 \%)$ address the social and environmental dimensions only. Lastly, 6 papers $(9.83 \%)$ consider the social dimension only, 5 papers $(8 \%)$ consider the economic dimension alone and 2 papers ( $3 \%$ ) only consider the environmental dimension (see Figure 3 ).

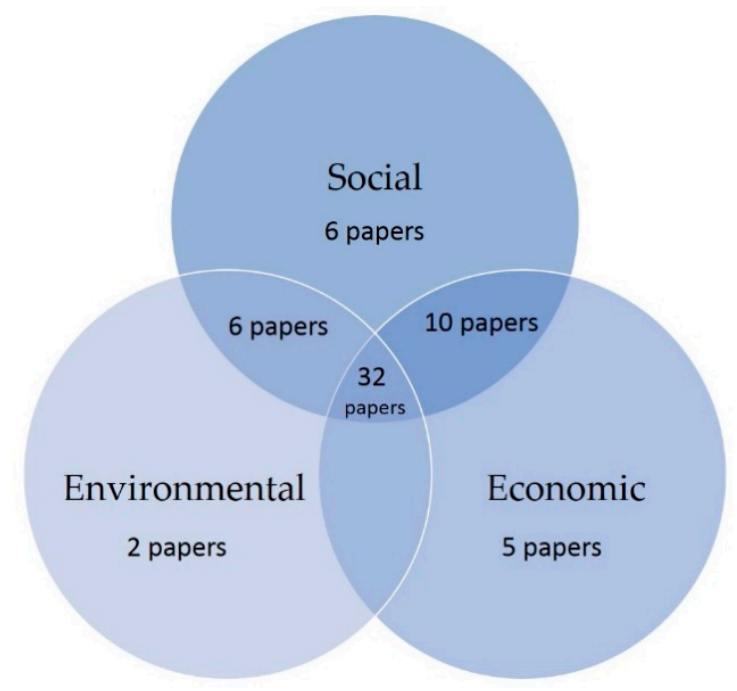

Figure 3. Sustainability dimensions addressed in papers of our sample. Note: Our elaboration.

To summarize, approximately half of the papers of our sample address the three most common dimensions of sustainability to some extent. The other half only addresses one or two dimensions. Overall, the social dimension received more attention than others as it was included in 48 papers $(78 \%)$ of our sample. This is followed by the economic dimension included in 47 papers $(77 \%)$ and the environmental dimension included in 40 papers $(65 \%)$. It is important to recognize that even papers that were classified as targeting the three main dimensions do not always address all the three dimensions to the same degree. They were sorted under this classification if they mentioned all the dimensions and discussed them in the context of their research to some extent.

Figure 4 shows the sustainability dimensions addressed in papers that involved 'producers' as participants in their research. Almost half of the papers that involved producers looked at the three dimensions of sustainability. The other half only looked at one or two dimensions of sustainability.

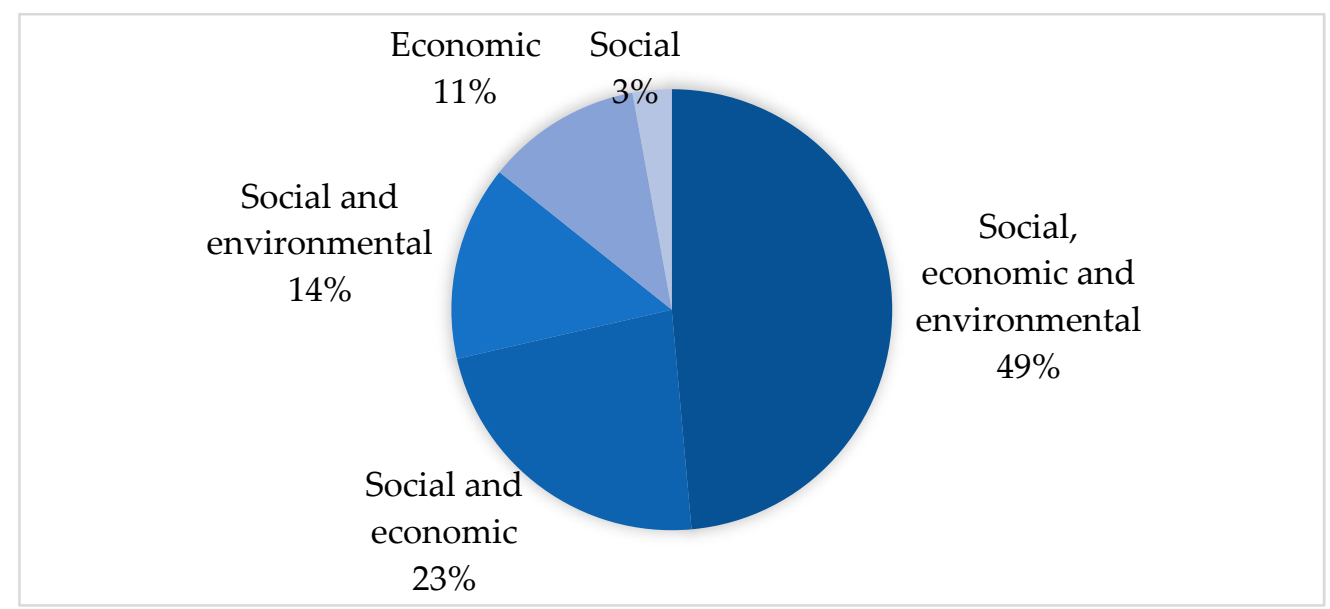

Figure 4. Sustainability dimensions addressed in papers that involved producers as participants. Note: Our elaboration. 
Figure 5 shows the sustainability dimensions addressed in papers that involved 'consumers' as participants in their research. Results are similar to those obtained from Figure 4 . Half of the papers that involved consumers as participants in their research looked at the three main dimensions of sustainability too. However, no papers involving consumers as participants looked at the economic dimension in isolation, whereas $11 \%$ of the papers involving producers as participants looked at the economic dimension only. Results in Figure 5 also suggest that all the papers that involved consumers as participants looked at the social dimension of sustainability. Overall, authors seem to have focused slightly less on the environmental dimension $(65 \%)$ than on other dimensions of sustainability.

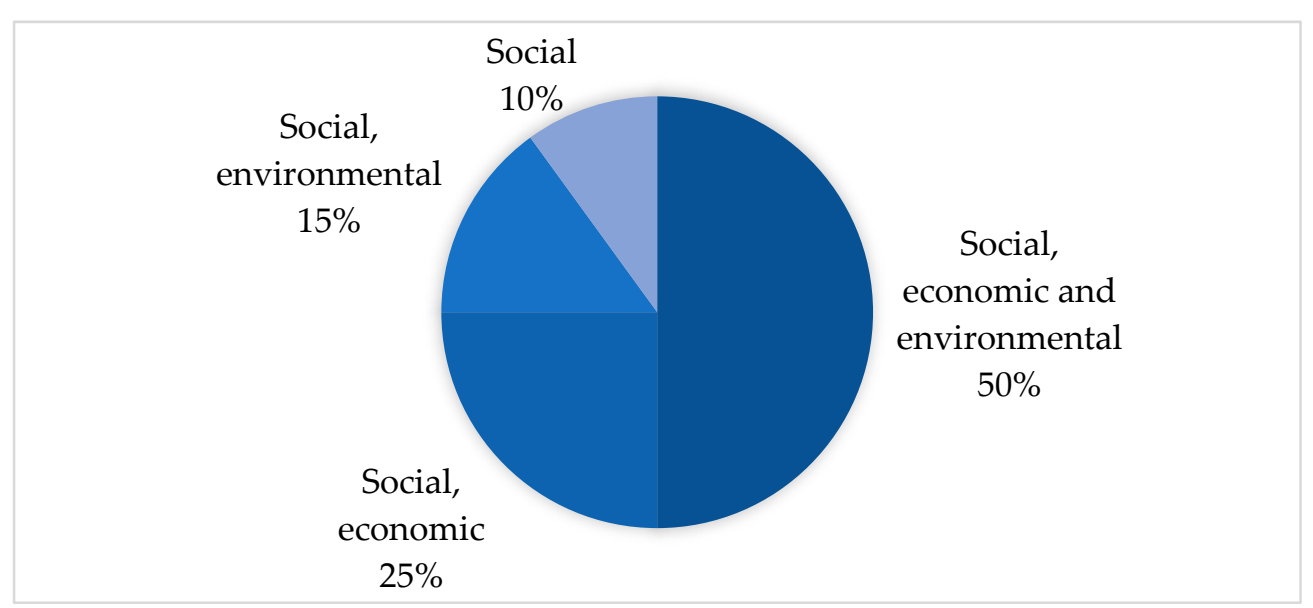

Figure 5. Sustainability dimensions addressed in papers that involved consumers as participants. Note: Our elaboration.

We identified that only 14 papers out of 61 in our sample involved both 'producers' and 'consumers' (main actors in AFNs) as participants in their research design (see Figure 6). From those 14 papers, $43 \%$ looked at the three main dimensions of sustainability and the rest looked at one or two dimensions only. In line with previous results, all 14 papers looked at the social dimension and the study of the environmental dimension was less prominent $(57 \%)$.

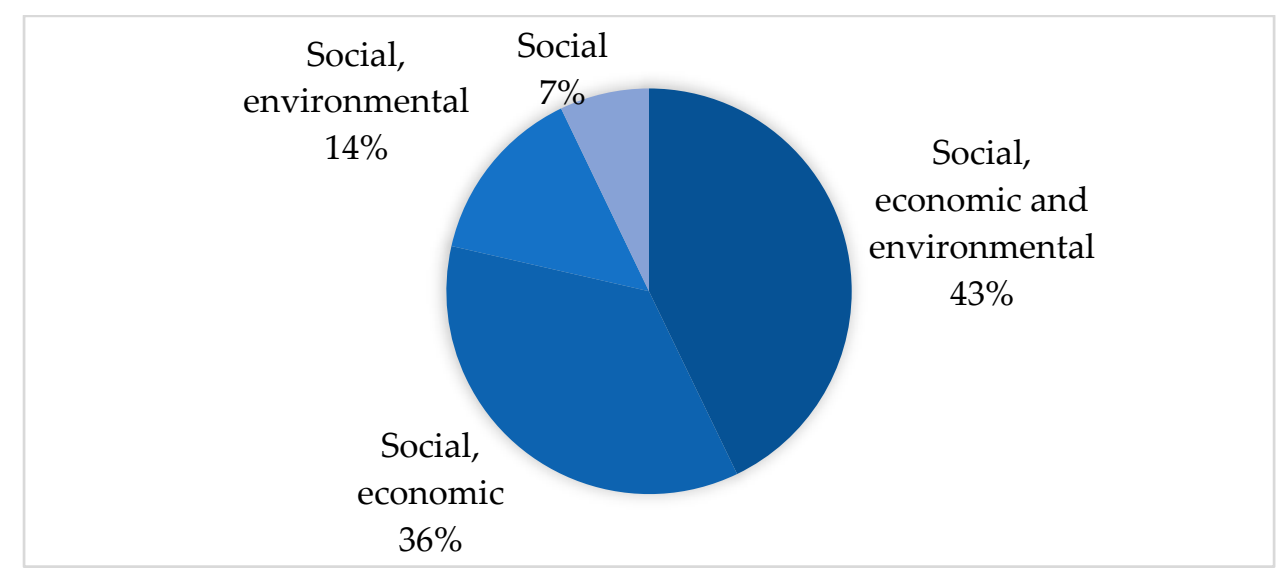

Figure 6. Sustainability dimensions addressed in papers that involved producers and consumers as participants. Note: Our elaboration.

The next stage of our analysis involved some cross-tabulations to further understand how sustainability has been studied within AFNs literature in relation to the number of different participants and AFNs configurations targeted in papers. The first cross-tabulation (Table 6) shows the relationship between sustainability dimensions addressed in papers of our sample and the number of different 
participants involved in the studies. For papers that address the three main dimensions of sustainability, we can observe that the majority (43\%) only involved one type of participant (from those cited in Table 5). As the number of types of participants involved in the studies increases, the number of papers addressing the three main dimensions decreases.

Table 6. Relationship between sustainability dimensions and amount of types of participants. Note: Our elaboration.

\begin{tabular}{cccccc}
\hline & & \multicolumn{4}{c}{ Types of Participants } \\
\cline { 3 - 5 } & & One & Two & Three & $>$ Four \\
\hline \multirow{3}{*}{$\begin{array}{c}\text { Sustainability } \\
\text { dimensions }\end{array}$} & Economic & 3 & 1 & 0 & 0 \\
& Social & 1 & 1 & 1 & 0 \\
& Social and economic & 1 & 4 & 1 & 2 \\
& Social and environmental & 3 & 1 & 2 & 0 \\
& Social, economic and environmental & 10 & 5 & 4 & 4 \\
\hline
\end{tabular}

The second cross-tabulation (Table 7) displays the relationship between sustainability dimensions addressed and the number of different types of AFNs arrangements researched in papers. The last row shows that the majority of papers $(76.5 \%)$ that address the three main dimensions of sustainability only looked at one type of AFN (from those displayed in Table 3). Results also show that papers that looked at more than five types of AFNs only addressed one dimension of sustainability.

Table 7. Relationship between sustainability dimensions and number of types of AFNs studied. Note: Our elaboration.

\begin{tabular}{cccccc}
\hline & & \multicolumn{3}{c}{ Types of AFNs } \\
\cline { 2 - 5 } & & One & Two & Four & > Five \\
\hline \multirow{3}{*}{ Sustainability } & Economic & 2 & 0 & 0 & 1 \\
dimensions & Environmental & 1 & 0 & 0 & 0 \\
& Social & 2 & 0 & 1 & 1 \\
& Social and economic & 3 & 1 & 1 & 0 \\
& Social and environmental & 4 & 1 & 0 & 0 \\
\hline
\end{tabular}

Lastly, a thematic analysis identified the main topics covered regarding the three dimensions of sustainability. Some topics covered in relation to the economic dimension are local economy, income, entrepreneurship, competitiveness, cultural economy, neoliberalism, consumer behavior, consumer sovereignty, experience economy, diverse economies, retailing, moral economy, circular economy, eco-economy, negotiation, ethical consumption and sharing economy. As suggested previously, the social dimension of sustainability has received more attention than others in the context of AFNs literature. Some topics studied in relation to the social dimension are models of labor, cooperation and solidarity, social innovation, ethics, cultural capital, communication, corporate social responsibility, embeddedness, social justice, food activism and social capital. Some prominent topics in relation to the environmental dimension are ecology, organic agriculture, certification, agroecology and landscape protection.

Thematic analysis also identified some of the frameworks used to examine sustainability in AFNs. Frameworks include tactile spaces [26], development economics theory of urban bias [52], food utopia [53], multifunctionality [54], political ecology [30], viable system model [55] and convention theory $[35,56]$. It is also important to note that no frameworks for the assessment of the three dimensions of sustainability based on indicators or metrics were used in the papers of our sample. 


\section{Discussion}

The first impression that emerges from the results of the present SLR is that the interest in pursuing research related to sustainability within AFNs has significantly increased since 2015. It is also noticeable that most studies have focused on a single country, with the USA and countries in Europe accounting for $75 \%$ of the sample. Little research has been conducted in developing countries located in the Global South. Because sustainability is dependable on political, socio-economic and environmental regional characteristics, the current bias in geographical distribution of AFNs research may hinder the generalization of findings. Furthermore, the uniqueness of other AFNs arrangements, which is dependable on the context [23], may remain unexplored. Thus, it is believed that further research targeting Africa, Asia and Latin America, as well as cross-country research, is needed.

Based on the results emerging from the collected data, we can now start answering our research questions. The first research question proposed in the introduction of this paper was the following:

RQ1. What methodological approaches have been used in the study of sustainability within AFNs?

The analyzed sample shows a predominance of empirical studies regarding sustainability in AFNs. A wide variety of research methods from different methodological backgrounds has been employed. However, the most common approach would be an empirical study using interviews and involving producers. Participant observation is another method that was used in many studies of our sample. Interestingly, this seems to be a method that lends itself to the study of AFNs. Some authors reported joining AFNs in order to collect data and gain in-depth insights.

The majority of empirical studies involved producers as participants addressing what could be termed as 'sustainable production'. Consumers were involved in less than half of the studies that looked at what we could call 'sustainable consumption'. Interestingly, only $22 \%$ of the papers involved both consumers and producers. In other words, only $22 \%$ of papers looked at both sustainable production and consumption within AFNs. For instance, one paper looks at sustainability of AFNs by studying a Community-Supported Agriculture (CSA) model from the perspective of producers only [22]. Another one looks at another CSA model but from the consumers' perspective instead [26]. We argue that the sustainability of AFNs may depend on both (and more) actors or stakeholders and therefore greater efforts are needed to ensure that sustainability of AFNs is studied through more holistic approaches. Such approaches may help uncover the complexity of interconnections by bringing together different perspectives.

RQ2. What types of AFNs have been studied in relation to sustainability?

A wide variety of AFNs arrangements have been examined within our sample. Overall, 19 different AFNs were identified. Even though the CSA model is the most common in our sample, it only appears in $15 \%$ of the papers. Farmers' markets, which are one of the most widespread, promoted and funded forms of AFNs [57-59], are included in only 13.7\% of the papers.

Some papers in the sample $[56,60,61]$ looked at one particular type of AFN that is particular to Italy, the Solidarity Purchasing Group (GAS). As would be expected, this type of AFN was studied by conducting research in Italy, its country of origin. The identification of an AFN that is native to a particular place or country within our sample further supports our previous argument regarding the need to conduct research in places that have not received attention yet.

Most recent papers $[62,63]$ have started to examine Community Gardens as another form of AFN. This is often done in the context of urban agriculture. Another recent paper studied a Wild Food Network [64], which authors conceptualize as an emerging form of AFN.

In terms of the number of different types of AFNs examined in empirical papers, findings suggest that the majority (71\%) of studies only look at one type of AFNs. Thus, the comparison of different types of AFNs within papers addressing sustainability is limited. This could mean that findings regarding sustainability in one specific type of AFN may not be transferable to other AFNs arrangements. We argue that there is an opportunity for future research to test findings from specific AFNs in other forms 
of AFNs. This could also be addressed by including the comparison of different types of AFNs in the research design.

RQ3. What dimensions of sustainability (i.e., social, economic and environmental) have been studied within AFNs literature?

From the results of this SLR, we can observe that $52 \%$ of papers in our sample consider the three main dimensions of sustainability. This means that almost half of the papers only address issues related to one or two dimensions of sustainability. These findings are in line with criticisms from Forssell and Lankoski [35] who suggest that more robust theories of sustainability within AFNs have not been developed because studies often focus on particular issues of sustainability.

Results from cross-tabulations show that almost half of the papers in our sample (43.5\%) addressing the three main dimensions of sustainability only involve one type of participant. Furthermore, most papers $(76.5 \%)$ addressing the three dimensions of sustainability only look at one type of AFN. This further confirms our findings regarding limited comparison of types of AFNs in the context of sustainability. Interestingly, papers that look at only one dimension of sustainability tend to examine more types of AFNs.

Overall, the social dimension of sustainability has received more attention than others (95\%), followed by the economic dimension (77\%). Interestingly, the environmental dimension has been examined in only $65 \%$ of the papers within the sample. This is contrary to the rationale followed by sustainability assessment frameworks for 'conventional' food systems, which shows that priority is given to the environmental side of sustainability [65]. In their study, Schader et al. [65] reviewed thirty-five sustainability frameworks and found that all approaches examine the environmental dimension and only $54 \%$ look at the social dimension. Similar to our results, they report that $48 \%$ of their reviewed frameworks examine the three dimensions of sustainability.

Overall, there is an opportunity for future research to adopt a more comprehensive approach by examining the three main dimensions of sustainability, which are expected to be in balance $[35,66]$. This would allow a closer examination of possible trade-offs among the three dimensions of sustainability in the context of AFNs.

\section{Conclusions}

The aim of this paper was to shed some light on how sustainability has been studied in AFNs literature. To this end, we examined the methodological approaches adopted, types of AFNs discussed, and sustainability dimensions investigated in journal articles. By conducting a SLR, we obtained a comprehensive view of the study of this topic. Furthermore, we were able to assess the validity of previous criticisms regarding sustainability in AFNs and propose opportunities for future research. However, we acknowledge limitations in our research. Because of the established inclusion and exclusion criteria, choice of database and choice of keywords, not all potential sources of information were included in the review. Our study also adopted the theoretical perspective that uses the concept of AFNs to characterize 'alternative' initiatives. Thus, other more recent theoretical perspectives and concepts were not adopted and investigated. Furthermore, the potential subjectivity introduced by the authors during the thematic analysis could be seen as a limitation too.

Our findings suggest that no frameworks based on metrics and indicators have been used for the evaluation of the three dimensions of sustainability in AFNs. This is surprising considering that AFNs are largely regarded as being more sustainable than the 'conventional' food system. This suggests that more efforts are needed to establish a common language of sustainability for the study of AFNs. There is a need to develop more transparent and comparable frameworks that can start to explore the sustainability assumptions within diverse AFNs. There is also an opportunity to test existing frameworks for the assessment of farming systems and supply chains and networks in the context of AFNs. This could shed some light on how AFNs are actually alternative or oppositional to the 'conventional' food systems in regards to sustainability. Although AFNs are supposed to enhance 
re-distribution of value for producers and to promote sustainable production, little attention is put on the value creation mechanisms $[67,68]$.

We found that articles published from 2006 to 2017 have addressed the three dimensions of sustainability to different degrees and have adopted a variety of methodological approaches. However, we also identified the need to adopt more holistic research approaches that allow the evaluation of trade-offs and balance among the social, economic and environmental sustainability within AFNs. From the cross-tabulation analyses, we can conclude that the number of papers addressing the three dimensions of sustainability and involving more than two stakeholders is very limited. Similarly, the number of papers addressing the three dimensions of sustainability and using more than one type of AFNs is scarce. We encourage efforts that look at the economic, social and environmental dimensions of sustainability in a balanced and integrated manner within different types of AFNs, considering the point of view of all main stakeholders. Lastly, we stress the importance of investigating the sustainability of AFNs in developing countries, which seems largely overlooked in the journals we considered.

Author Contributions: Conceptualization, R.M.V.; writing—original draft preparation, R.M.V.; writing—review and editing, R.M.V., M.H., M.C., I.B.; supervision, M.H.; visualization, R.M.V., M.H., M.C., I.B.; project administration, R.M.V., M.H., M.C., I.B.

Funding: This research received no external funding.

Conflicts of Interest: The authors declare no conflict of interest.

\section{Appendix A}

Table A1. The 61 papers included in the final sample of our SLR.

\begin{tabular}{l}
\hline Papers \\
\hline Holloway, L.; Cox, R.; Venn, L.; Kneafsey, M.; Dowler, E.; Tuomainen, H. Managing Sustainable Farmed \\
Landscape through 'Alternative' Food Networks: A Case Study from Italy. The Geographical Journal 2006, 172, \\
219-229. \\
\hline Maxey, L. Can we sustain sustainable agriculture? Learning from small-scale producer-suppliers in Canada \\
and the UK. The Geographical Journal 2006, 172, 230-244, doi:10.1111/j.1475-4959.2006.00211.x \\
\hline Trauger, A. Un/Re-Constructing The Agrarian Dream: Going Back-To-The-Land With An Organic Marketing \\
Co-Operative In South-Central Pennsylvania, Usa. Tijdschrift Voor Economische En Sociale Geografie 2007, 98, \\
9-20, doi:10.1111/j.1467-9663.2007.00372.x \\
\hline Seyfang, G. 'Avoiding Asda? Exploring Consumer Motivations In Local Organic Food Networks'. Local \\
Environment 2008, 13, 187-201, doi:10.1080/13549830701669112 \\
\hline Jarosz, L. The city in the country: Growing alternative food networks in Metropolitan areas. Journal of Rural \\
Studies 2008, 24, 231-244, doi:10.1016/j.jrurstud.2007.10.002 \\
\hline Hernández, J.L.S. Alternative food networks: Concept, typology and adaptation to the Spanish context [Redes \\
alimentarias alternativas: Concepto, tipología y adecuación a la realidad Española], Boletin de la Asociacion de \\
Geografos Espanoles 2009, 49, 185-207. \\
\hline Sims, R. Food, place and authenticity: local food and the sustainable tourism experience. Journal of Sustainable \\
Tourism 2009, 17, 321-336, doi:10.1080/09669580802359293 \\
\hline Zagata, L. The analysis of the current forms of organic chicken husbandry in the Czech Republic and their \\
social consequences. Agricultural Economics-Zemedelska Ekonomika 2009, 55, 271-283. \\
\hline Hayden, J.; Buck, D. Doing community supported agriculture: Tactile space, affect and effects of membership. \\
Geoforum 2012, 43, 332-341, doi:10.1016/j.geoforum.2011.08.003 \\
\hline Hilimire, K. The grass is greener: Farmers' experiences with pastured poultry. Renewable Agriculture and Food \\
Systems 2012, 27, 173-179, doi:10.1017/S1742170511000287 \\
\hline
\end{tabular}


Table A1. Cont.

\begin{tabular}{|c|}
\hline Papers \\
\hline $\begin{array}{l}\text { Smith, J.; Jehlicka, P. Quiet sustainability: Fertile lessons from Europe's productive gardeners. Journal of Rural } \\
\text { Studies 2013, 32, 148-157, doi:10.1016/j.jrurstud.2013.05.002 }\end{array}$ \\
\hline $\begin{array}{l}\text { Melo, C.J.; Hollander, G.M. Unsustainable development: Alternative food networks and the Ecuadorian } \\
\text { Federation of Cocoa Producers, 1995-2010. Journal of Rural Studies 2013, 32, 251-263. }\end{array}$ \\
\hline $\begin{array}{l}\text { Fonte, M. Food consumption as social practice: Solidarity Purchasing Groups in Rome, Italy. Journal of Rural } \\
\text { Studies 2013, 32, 230-239. }\end{array}$ \\
\hline $\begin{array}{l}\text { Tudisca, S.; Di Trapani, A.M.; Sgroi, F.; Testa, R.; Giamporcaro, G. Role of alternative food networks in Sicilian } \\
\text { farms. International Journal of Entrepreneurship and Small Business 2014, 22, doi:10.1504/IJESB.2014.062130 }\end{array}$ \\
\hline $\begin{array}{l}\text { Forssell, S.; Lankoski, L. The sustainability promise of alternative food networks: an examination through } \\
\text { "alternative" characteristics. Agriculture and Human Values 2014, 32, 63-75, doi:10.1007/s10460-014-9516-4 }\end{array}$ \\
\hline $\begin{array}{l}\text { Smeds, J. Growing through Connections-A Multi-Case Study of Two Alternative Food Networks in } \\
\text { Cluj-Napoca, Romania. Future of Food: Journal on Food, Agriculture and Society 2015, 2, 48-61. }\end{array}$ \\
\hline $\begin{array}{l}\text { McClintock, N. Radical, reformist, and garden-variety neoliberal: coming to terms with urban agriculture's } \\
\text { contradictions. Local Environment 2014, 19,147-171, doi:10.1080/13549839.2012.752797 }\end{array}$ \\
\hline $\begin{array}{l}\text { Carlisle, L. Audits and agrarianism: The moral economy of an alternative food network. Elem. Sci. Anth. 2015, } \\
\text { 3, doi:10.12952/journal.elementa.000066 }\end{array}$ \\
\hline $\begin{array}{l}\text { Sovová, L. Self-provisioning, sustainability and environmental consciousness in brno allotment gardens. } \\
\text { Socialni Studia/Social Studies } \mathbf{2 0 1 5 , 1 2 .}\end{array}$ \\
\hline $\begin{array}{l}\text { Paltrinieri, R.; Spillare, S. Well-being shift through healthy eating. From organic consumption to a paradigm of } \\
\text { alternative local development. Rivista Di Studi Sulla Sostenibilita' } 2015,2,83-94 \text {. }\end{array}$ \\
\hline $\begin{array}{l}\text { Sassatelli, R. Consumer Culture, Sustainability and a New Vision of Consumer Sovereignty. Sociologia Ruralis } \\
\text { 2015, 483-496, doi:10.1111/soru.12081 }\end{array}$ \\
\hline $\begin{array}{l}\text { Sidali, K.L.; Kastenholz, E.; Bianchi, R. Food tourism, niche markets and products in rural tourism: combining } \\
\text { the intimacy model and the experience economy as a rural development strategy. Journal of Sustainable Tourism } \\
\text { 2015, 23, 1179-1197, doi:10.1080/09669582.2013.836210 }\end{array}$ \\
\hline $\begin{array}{l}\text { Miller, W.M. UK allotments and urban food initiatives: (limited?) potential for reducing inequalities. Local } \\
\text { Environment 2015, 20, 1194-1214, doi:10.1080/13549839.2015.1035239 }\end{array}$ \\
\hline $\begin{array}{l}\text { Williams, L.T.; Germov, J.; Fuller, S.; Freij, M. A taste of ethical consumption at a slow food festival. Appetite } \\
\text { 2015, 91, 321-328, doi:10.1016/j.appet.2015.04.066 }\end{array}$ \\
\hline $\begin{array}{l}\text { Carolan, M. Affective sustainable landscapes and care ecologies: getting a real feel for alternative food } \\
\text { communities. Sustainability Science 2015, 10, 317-329. }\end{array}$ \\
\hline $\begin{array}{l}\text { Syrovatkova, M.; Hrabak, J.; Spilkova, J. Farmers' markets' locavore challenge: The potential of local food } \\
\text { production for newly emerged farmers' markets in Czechia. Renewable Agriculture and Food Systems 2015, 30, } \\
\text { 305-317, doi:10.1017/S1742170514000064 }\end{array}$ \\
\hline $\begin{array}{l}\text { Syrovatkova, M. The adoption of a local food concept in post-communist context: Farm shops in Czechia. } \\
\text { Norsk Geografisk Tidsskrift - Norwegian Journal of Geography 2016, 70, 24-40, doi:10.1080/00291951.2015.1125942 }\end{array}$ \\
\hline $\begin{array}{l}\text { Torquati, B.; Viganò, E.; Taglioni, C. Construction of alternative food networks for organic products: A case } \\
\text { study of "organized Groups of Supply and Demand". New Medit 2016, 15,53-62. }\end{array}$ \\
\hline $\begin{array}{l}\text { James, S.W. Beyond "local' food: how supermarkets and consumer choice affect the economic viability of } \\
\text { small-scale family farms in Sydney, Australia. AREA 2016, 48, 103-110. }\end{array}$ \\
\hline $\begin{array}{l}\text { Terziev, V.; Arabska, E. Sustainable rural development through organic production and community-supported } \\
\text { agriculture in Bulgaria. Bulgarian Journal of Agricultural Science 2016, 22, 527-535. }\end{array}$ \\
\hline $\begin{array}{l}\text { Dixon, J.; Richards, C. On food security and alternative food networks: understanding and performing food } \\
\text { security in the context of urban bias. Agriculture and Human Values 2016, 33, 191-202. }\end{array}$ \\
\hline $\begin{array}{l}\text { Wald, N.; Hill, D.P. 'Rescaling' alternative food systems: from food security to food sovereignty. Agriculture and } \\
\text { Human Values 2016, 33, 203-213. }\end{array}$ \\
\hline $\begin{array}{l}\text { de Luca, A.I.; Stillitano, T.; Franco, F.A.; Gulisano, G. Convention theory and the assessment of socio-econon } \\
\text { sustainability of alternative food networks in Calabria (South Italy). Quality - Access to Success 2016, 17, 85- }\end{array}$ \\
\hline
\end{tabular}


Table A1. Cont.

\begin{tabular}{l}
\hline Papers \\
\hline Omoto, R.; Scott, S. Multifunctionality and agrarian transition in alternative agro-food production in the global \\
South: The case of organic shrimp certification in the Mekong Delta, Vietnam. Asia Pacific Viewpoint 2016, 57, \\
121-137. \\
\hline Bos, E.; Owen, L. Virtual reconnection: The online spaces of alternative food networks in England. Journal of \\
Rural Studies 2016, 45, 1-14, doi:10.1016/j.jrurstud.2016.02.016 \\
\hline Touri, M. Development communication in alternative food networks: empowering Indian farmers through \\
global market relations. The Journal of International Communication 2016, 22, 209-228, \\
doi:10.1080/13216597.2016.1175366 \\
\hline Weiler, A.M.; Otero, G.; Wittman, H. Rock Stars and Bad Apples: Moral Economies of Alternative Food \\
Networks and Precarious Farm Work Regimes. Antipode 2016, 48, 1140-1162, doi:10.1111/anti.12221 \\
\hline Turner, K.L.; Davidson-Hunt, I.J.; Desmarais, A.A.; Hudson, I. Creole hens and ranga-ranga: Campesino \\
foodways and biocultural resource-based development in the Central Valley of Tarija, Bolivia. Agriculture 2016, \\
6, 41, doi:10.3390/agriculture6030041 \\
\hline Barnett, M.J.; Dripps, W.R.; Blomquist, K.K. Organivore or organorexic? Examining the relationship between \\
alternative food network engagement, disordered eating, and special diets. Appetite 2016, 1, 713-720, \\
doi:10.1016/j.appet.2016.07.008.
\end{tabular}

Kristensen, D.K.; Kjeldsen, C.; Thorsøe, M.H. Enabling Sustainable Agro-Food Futures: Exploring Fault Lines and Synergies Between the Integrated Territorial Paradigm, Rural Eco-Economy and Circular Economy. Journal of Agricultural and Environmental Ethics 2016, 29, 749-765.

Hedberg, R.C. The ecology of alternative food landscapes: a framework for assessing the ecology of alternative food networks and its implications for sustainability. Landscape Research 2016, 41, 795-807, doi:10.1080/01426397.2015.1074168

Doernberg, A.; Zasada, I.; Bruszewska, K.; Skoczowski, B.; Piorr, A. Potentials and Limitations of Regional Organic Food Supply: A Qualitative Analysis of Two Food Chain Types in the Berlin Metropolitan Region. Sustainability 2016, 8, 1125, doi:10.3390/su8111125

Bui, S.; Cardona, A.; Lamine, C.; Cerf, M. Sustainability transitions: Insights on processes of niche-regime interaction and regime reconfiguration in agri-food systems. Journal of Rural Studies 2016, 48, 92-103, doi:10.1016/j.jrurstud.2016.10.003

Pinna, S. Sowing landscapes: Social and ecological aspects of food production in peri-urban spatial planning initiatives - a study from the Madrid area. Future of Food: Journal on Food, Agriculture and Society 2017, 5, $34-45$.

Rover, O.J.; de Gennaro, B.C.; Roselli, L. Social Innovation and Sustainable Rural Development: The Case of a Brazilian Agroecology Network. Sustainability 2017, 9, 3, doi:10.3390/su9010003

Barta, A. Habitus in alternative food practice: Exploring the role of cultural capital in two contrasting case studies in Glasgow. Future of Food: Journal on Food, Agriculture and Society 2017, 5, 27-41.

Bellante, L. Building the local food movement in Chiapas, Mexico: rationales, benefits, and limitations. Agriculture and Human Values 2017, 34, 119-134.

Rossi, A. Beyond food provisioning: The transformative potential of grassroots innovation around food. Agriculture 2017, 7, 6, doi:10.3390/agriculture7010006

DesRivières, C.P.; Chuenpagdee, R.; Mather, C. Reconnecting people, place, and nature: Examining alternative food networks in Newfoundland's fisheries. Agriculture \& Food Security 2017, 6, doi:10.1186/s40066-017-0112-x

Tavella, E.; Papadopoulos, T. Applying OR to problem situations within community organisations: A case in a Danish non-profit, member-driven food cooperative. European Journal of Operational Research 2017, 258, 726-742.

Mitchell, I.K.; Low, W.; Davenport, E.; Brigham, T. Running wild in the marketplace: the articulation and negotiation of an alternative food network. Journal of Marketing Management 2017, 33, 502-528, doi:10.1080/0267257X.2017.1329224

Sarmiento, E.R. Synergies in alternative food network research: embodiment, diverse economies, and more-than-human food geographies. Agriculture and Human Values 2017, 34, 485-497.

Duncan, J.; Pascucci, S. Mapping the Organisational Forms of Networks of Alternative Food Networks: Implications for Transition. Sociologia Ruralis 2017, 57, 316-339, doi:10.1111/soru.12167 
Table A1. Cont.

\begin{tabular}{l}
\hline Papers \\
\hline Jehlicka, P.; Danek, P. Rendering the Actually Existing Sharing Economy Visible: Home-Grown Food and the \\
Pleasure of Sharing. Sociologia Ruralis 2017, 57, 274-296, https:/ / doi.org/10.1111/soru.12160 \\
\hline de Hoop, E.; Jehlička, P. Reluctant pioneers in the European periphery? Environmental activism, food \\
consumption and “growing your own”. Local Environment 2017, 22, 809-824, \\
doi:10.1080/13549839.2017.1289160 \\
\hline Thornton, A. “The Lucky country”? A critical exploration of community gardens and city-community \\
relations in Australian cities. Local Environment 2017, 22, 969-985, doi:10.1080/13549839.2017.1317726 \\
\hline Barlett, P.F. Campus Alternative Food Projects and Food Service Realities: Alternative Strategies. Human \\
Organization 2017, 76, 189-203. \\
\hline Forssell, S.; Lankoski, L. Navigating the tensions and agreements in alternative food and sustainability: a \\
convention theoretical perspective on alternative food retail. Agriculture and Human Values 2017, 34, 513-527. \\
\hline Bruce, A.B.; Castellano, R.L.S. Labor and alternative food networks: challenges for farmers and consumers. \\
Renewable Agriculture and Food Systems 2017, 32, 403-416, doi:10.1017/S174217051600034X \\
\hline Miralles, I.; Dentoni, D.; Pascucci, S. Understanding the organization of sharing economy in agri-food systems: \\
evidence from alternative food networks in Valencia. Agriculture and Human Values 2017, 34, 833-854, \\
doi:10.1007/s10460-017-9778-8 \\
\hline Randelli, F;; Rocchi, B. Analysing the role of consumers within technological innovation systems: The case of \\
alternative food networks. Environmental Innovation and Societal Transitions 2017, 25, 94-106, \\
doi:10.1016/j.eist.2017.01.001
\end{tabular}

\section{References}

1. World Commision on Environment and Development. Our Common Future; Oxford Univresity Press: New York, NY, USA, 1987.

2. McKibben, B. Deep Economy: Economics as If the World Mattered; Holt Paperbacks: New York, NY, USA, 2007.

3. Rockström, J.; Steffen, W.; Noone, K.; Persson, A.; Chapin, F.S.; Lambin, E.F.; Lenton, T.M.; Scheffer, M.; Folke, C.; Schellnhuber, H.J.; et al. A safe operating space for humanity. Nature 2009, 461, 472-475. [CrossRef] [PubMed]

4. FAO. Statistical Yearbook of World Food and Agriculture for the United Nations; FAO: Rome, Italy, 2013.

5. United Nations. Zero Hunger: Why It Matters; United Nations: New York, NY, USA, 2016. Available online: https:/ / www.un.org/sustainabledevelopment/wp-content/uploads/2018/09/Goal-2.pdf (accessed on 20 December 2018).

6. FAO; IFAD; UNICEF; WFP; WHO. The State of Food Security and Nutrition in the World 2017. Building Resilience for Peace and Food Security; FAO: Rome, Italy, 2017.

7. Castaneda Aguilar, R.A.; Doan, D.T.T.; Newhouse, D.L.; Nguyen, M.C.; Uematsu, H.; Azevedo, J.P.W.D. Who Are the Poor in the Developing World? Policy Research Working Paper no. WPS 7844; World Bank Group: Washington, DC, USA, 2016.

8. Hardin, G. The theory of the Commons. Science 1968, 162, 1243-1248.

9. Dietz, T.; Ostrom, E.; Stern, P.C. The Struggle to Govern the Commons. Science 2003, 302, $1907-1912$. [CrossRef]

10. Sonnino, R.; Marsden, T. Beyond the divide: Rethinking relationships between alternative and conventional food networks in Europe. J. Econ. Geogr. 2006, 6, 181-199. [CrossRef]

11. Beus, C.E.; Dunlap, R.E. Conventional versus Alternative Agriculture: The Paradigmatic Roots of the Debate. Rural Sociol. 1990, 55, 590-616. [CrossRef]

12. Ericksen, P.J. Conceptualizing food systems for global environmental change research. Glob. Environ. Chang. 2007. [CrossRef]

13. Bazzani, C.; Canavari, M. Alternative Agri-Food Networks and Short Food Supply Chains: A review of the literature. Econ. Agro-Aliment. 2013, 15, 11-34. [CrossRef]

14. Goodman, D.; DuPuis, E.M.; Goodman, M.K. Alternative Food Networks: Knowledge, Practice, and Politics; Routledge: New York, NY, USA, 2012. 
15. Sage, C. Social embeddedness and relations of regard: Altenrative 'good food' networks in south-west Ireland. J. Rural Stud. 2003, 19, 47-60. [CrossRef]

16. Watts, D.C.H.; Ilbery, B.; Maye, D. Making reconnections in agro-food geography: Alternative systems of food provision. Prog. Hum. Geogr. 2005, 29, 22-40. [CrossRef]

17. Renting, H.; Marsden, T.; Banks, J. Understanding alternative food networks: Exploring the role of short food supply chains in rural development. Environ. Plan. A 2003, 35, 393-411. [CrossRef]

18. Renting, H.; Schermer, M.; Rossi, A. Building Food Democracy: Exploring Civic Food Networks and Newly Emerging Forms of Food Citizenship. Int. J. Sociol. Agric. Food 2012, 19, $289-307$.

19. Bos, E.; Owen, L. Virtual reconnection: The online spaces of alternative food networks in England. J. Rural Stud. 2016, 45, 1-14. [CrossRef]

20. Feenstra, G. Local food systems and sustainable communities. Am. J. Altern. Agric. 1997, 12, 28-36. [CrossRef]

21. Jarosz, L. The city in the country: Growing alternative food networks in Metropolitan areas. J. Rural Stud. 2008, 24, 231-244. [CrossRef]

22. Holloway, L.; Cox, R.; Venn, L.; Kneafsey, M.; Dowler, E.; Tuomainen, H. Managing sustainable farmed landscape through 'alternative' food networks: A case study from Italy. Geogr. J. 2006, 172, $219-229$. [CrossRef]

23. Maye, D.; Kirwan, J. Alternative Food Networks. Sociopedia.isa 2010. [CrossRef]

24. Kizos, T.; Vakoufaris, H. Alternative Agri-Food Geographies? Geographic Indications in Greece. Tijdschrift Voor Economische En Sociale Geografie 2011, 102, 220-235. [CrossRef]

25. Trauger, A. Un/re-constructing the agrarian dream: Going back-to-the-land with an organic marketing co-operative in south-central Pennsylvania, USA. Tijdschrift Voor Economische En Sociale Geografie 2007, 98, 9-20. [CrossRef]

26. Hayden, J.; Buck, D. Doing community supported agriculture: Tactile space, affect and effects of membership. Geoforum 2012, 43, 332-341. [CrossRef]

27. Turner, B.; Hope, C. Staging the Local: Rethinking scale in farmers' markets. Australian Geogr. 2015, 46, 147-163. [CrossRef]

28. Naylor, L. Hired gardens and the question of transgression: Lawns, food gardens and the business of 'alternative' food practice. Cult. Geogr. 2012, 19. [CrossRef]

29. Tregear, A. Progressing knowledge in alternative and local food networks: Critical reflections and a research agenda. J. Rural Stud. 2011, 27, 419-430. [CrossRef]

30. Bellante, L. Building the local food movement in Chiapas, Mexico: Rationales, benefits, and limitations. Agric. Hum. Values 2017, 34, 119-134. [CrossRef]

31. Born, B.; Purcell, M. Avoiding the Local Trap: Scale and Food Systems in Planning Research. J. Plan. Educ. Res. 2006, 26, 195-207. [CrossRef]

32. Michel-Villarreal, R.; Vilalta-Perdomo, E.; Hingley, M. The value of public data for assessing sustainability: The case of Mexican entrepreneurs and the rural census. In Sustainable Entrepreneurship: Discovering, Creating and Seizing Opportunities for Blended Value Generation; Lindgreen, A., Vallaster, C., Maon, F., Yousafzai, S., Palacios-Florencio, B., Eds.; Routledge: Abingdon, UK, 2018.

33. Michel-Villarreal, R.; Vilalta-Perdomo, E.; Hingley, M.; Canavari, M. Evaluating economic resilience for sustainable agri-food systems: The case of Mexico. Strateg. Chang. 2018, 28. [CrossRef]

34. Harris, E. Neoliberal subjectivities or a politics of the possible? Reading for difference in alternative food networks. Area 2009, 41, 55-63. [CrossRef]

35. Forssell, S.; Lankoski, L. The sustainability promise of alternative food networks: An examination through "alternative" characteristics. Agric. Hum. Values 2015, 32, 63-75. [CrossRef]

36. Hedberg, R.C. The ecology of alternative food landscapes: A framework for assessing the ecology of alternative food networks and its implications for sustainability. Landsc. Res. 2016, 41, 795-807. [CrossRef]

37. Caputo, V.; Vassilopoulos, A.; Nayga, R.M.; Canavari, M. Welfare Effects of Food Miles Labels. J. Consum. Aff. 2013, 47, 311-327. [CrossRef]

38. Bazzani, C.; Canavari, M. Is local a matter of food miles or food traditions? Ital. J. Food Sci. 2017, 29, 505-517. [CrossRef]

39. Kemp, K.; Insch, A.; Holdsworth, D.K.; Knight, J.G. Food miles: Do UK consumers actually care? Food Policy 2010, 35, 504-513. [CrossRef] 
40. Pretty, J.N.; Ball, A.S.; Lang, T.; Morison, J.I.L. Farm costs and food miles: An assessment of the full cost of the UK weekly food basket. Food Policy 2005, 30, 1-19. [CrossRef]

41. James, S.W. Beyond "local" food: How supermarkets and consumer choice affect the economic viability of small-scale family farms in Sydney, Australia. Area 2016, 48, 103-110. [CrossRef]

42. Adams, W.M. The Future of Sustainability: Re-Thinking Environment and Development in the Twenty-First Century; IUCN: Gland, Switzerland, 2006.

43. Giddings, B.; Hopwood, B.; O’Brien, G. Environment, Economy and Society: Fitting Them Together into Sustainable Development. Sustain. Dev. 2002, 10, 187-196. [CrossRef]

44. Purvis, B.; Mao, Y.; Robinson, D. Three pillars of sustainability: In search of conceptual origins. Sustain. Sci. 2018, 1-15. [CrossRef]

45. United Nations. Draft Outcome Document of the United Nations Summit for the Adoption of the Post-2015 Development Agenda; UN: New York, NY, USA, 2015.

46. United Nations. Integrating the Three Dimensions of Sustainable Development: A Framework and Tools; UN: New York, NY, USA, 2015.

47. Auler, D.P.; Teixeira, R.; Nardi, V. Food safety as a field in supply chain management studies: A systematic literature review. Int. Food Agribus. Manag. Rev. 2016, 20. [CrossRef]

48. Tranfield, D.; Denyer, D.; Smart, P. Towards a Methodology for Developing Evidence-Informed Management Knowledge by Means of Systematic Review. Br. J. Manag. 2003, 14, 207-222. [CrossRef]

49. Ferreira Gregorio, V.; Pié, L.; Terceño, A. A Systematic Literature Review of Bio, Green and Circular Economy Trends in Publications in the Field of Economics and Business Management. Sustainability 2018, 10, 4232. [CrossRef]

50. Piccarozzi, M.; Aquilani, B.; Gatti, C. Industry 4.0 in Management Studies: A Systematic Literature Review. Sustainability 2018, 10, 3821. [CrossRef]

51. Vieira de Carvalho, A.C.; Denis Granja, A.; Gomes da Silva, V. A Systematic Literature Review on Integrative Lean and Sustainability Synergies over a Building's Lifecycle. Sustainability 2018, 9, 1156. [CrossRef]

52. Dixon, J.; Richards, C. On food security and alternative food networks: Understanding and performing food security in the context of urban bias. Agric. Hum. Values 2016, 33, 191-202. [CrossRef]

53. Wald, N.; Hill, D.P. 'Rescaling' alternative food systems: From food security to food sovereignty. Agric. Hum. Values 2016, 33, 203-213. [CrossRef]

54. Omoto, R.; Scott, S. Multifunctionality and agrarian transition in alternative agro-food production in the global South: The case of organic shrimp certification in the Mekong Delta, Vietnam. Asia Pac. Viewp. 2016, 57, 121-137. [CrossRef]

55. Tavella, E.; Papadopoulos, T. Applying OR to problem situations within community organisations: A case in a Danish non-profit, member-driven food cooperative. Eur. J. Oper. Res. 2017, 258, 726-742. [CrossRef]

56. De Luca, A.I.; Stillitano, T.; Franco, F.A.; Gulisano, G. Convention theory and the assessment of socio-economic sustainability of alternative food networks in Calabria (South Italy). Qual. Access Success 2016, 17, 85-91.

57. Arabska, E. Farmers' markets as a business model encouraging sustainable production and consumption. Visegr. J. Bioeconomy Sustain. Dev. 2018, 7, 2-6. [CrossRef]

58. Gliddon, G. Libs to Support Farmers Markets. The Ballarat Courier, 8 March 2018.

59. Savoie-Roskos, M.R.; Wengreen, H.; Gast, J.; LeBlanc, H.; Durward, C. Understanding the Experiences of Low-Income Individuals Receiving Farmers' Market Incentives in the United States: A Qualitative Study. Health Promot. Pract. 2017, 18, 869-878. [CrossRef] [PubMed]

60. Fonte, M. Food consumption as social practice: Solidarity Purchasing Groups in Rome, Italy. J. Rural Stud. 2013, 32, 230-239. [CrossRef]

61. Tudisca, S.; Di Trapani, A.M.; Sgroi, F.; Testa, R.; Giamporcaro, G. Role of alternative food networks in Sicilian farms. Int. J. Entrep. Small Bus. 2014, 22, 50-63. [CrossRef]

62. Thornton, A. "The Lucky country"? A critical exploration of community gardens and city-community relations in Australian cities. Local Environ. 2017, 22, 969-985. [CrossRef]

63. Miralles, I.; Dentoni, D.; Pascucci, S. Understanding the organization of sharing economy in agri-food systems: Evidence from alternative food networks in Valencia. Agric. Hum. Values 2017, 4, 833-854. [CrossRef] 
64. Mitchell, I.K.; Low, W.; Davenport, E.; Brigham, T. Running wild in the marketplace: The articulation and negotiation of an alternative food network. J. Market. Manag. 2017, 33, 502-528. [CrossRef]

65. Schader, C.; Grenz, J.; Meier, M.S.; Stolze, M. Scope and precision of sustainability assessment approaches to food systems. Ecol. Soc. 2014, 19, 42. [CrossRef]

66. Maxey, L. Can we sustain sustainable agriculture? Learning from small-scale producer-suppliers in Canada and the UK. Geogr. J. 2006, 172, 230-244. [CrossRef]

67. Priem, R.L. A Consumer Perspective on Value Creation. Acad. Manag. Rev. 2007, 32, 219-235. [CrossRef]

68. Steiner, B.E. A phenomenon-driven approach to the study of value creation and organizational design issues in agri-business value chains. Econ. Agro-Aliment./Food Econ. 2017, 19, 89-118. [CrossRef]

2019 by the authors. Licensee MDPI, Basel, Switzerland. This article is an open access article distributed under the terms and conditions of the Creative Commons Attribution (CC BY) license (http://creativecommons.org/licenses/by/4.0/). 